\title{
RELIGIIAO, PATRIMONNIO HISTÓRICO E TURISMO NA SEMANA SANTA EM TIRADENTES (MG)
}

\author{
Marcelo Ayres Camurça \\ Oswaldo Giovannini Jr. \\ Universidade Federal de Juiz de Fora - Brasil
}

Resumo: Este artigo aborda, a partir do evento da Semana Santa em Tiradentes, cidade histórica e turística de Minas Gerais, a confluência de três visões de mundo: a religião católica tradicional, o patrimônio histórico e cultural e o turismo. Procura-se analisar como essas três concepções, através de seus agentes e suas instituições, de acordo com suas experiências históricas, culturais e estéticas, vão atribuir sentidos distintos aos mesmos fenômenos e objetos: igrejas, imagens sacras, procissões e cerimônias religiosas. Por fim, busca-se encaminhar uma reflexão sobre as interações entre as três dimensões e a resultante disso em termos de reinterpretações, negociações e competições entre elas.

Palavras-chave: patrimônio histórico, produção de sentido, religião, turismo

Abstract: Through an event, the Holy Week at Tiradentes, touristic destination and historical city of Minas Gerais (Brazil), the present article examines the meeting of three different views on the world - the traditional catholic religion, the cultural and historic patrimony, and tourism. Each of these three conceptions, by means of their agents and institutions, according to their own historical, cultural and aesthetic experiences, will give a different meaning to the very same phenomena and objects: churches, sacred images, religious processions and ceremonies. A reflection is also offered, analyzing the interactions between these three dimensions and the result of these interactions, as reinterpretations, negotiations, and competitions among them.

Keywords: historical patrimony, production of meanings, religion, tourism. 
Neste artigo procuraremos enfocar, a partir do evento da Semana Santa que se realiza em Tiradentes, cidade histórica do período colonial situada em Minas Gerais, a confluência de três concepções de mundo, a saber, a religião, a política de conservação histórica e cultural e o turismo, junto com as conseqüentes atividades advindas delas.

Observamos que a mesma paisagem urbana, com sua arquitetura, igrejas e imagens sacras, é passível de uma pluralidade de significações e usos por parte dessas três instâncias, que se antagonizam, superpõem-se, mas também negociam e combinam-se. Essas visões de mundo evidentemente provêm de instituições e seus agentes (Igreja Católica e seus fiéis locais, o patrimônio histórico e cultural e o complexo turístico), que de acordo com sua experiência histórica, social, cultural e estética vão atribuir sentidos singulares aos mesmos objetos sensíveis.

Como entendemos que todo e qualquer objeto, ato ou acontecimento só pode ter existência para uma cultura à medida que é inserido significativamente em um sistema (Lévi-Strauss, 1991), utilizaremos a categoria de estruturas de significado como instrumento que articula sentido, interesses e ação nos respectivos atores sociais: moradores da cidade católicos tradicionais, técnicos e turistas, em torno de suas instituições sociais: Igreja Católica, irmandades, IPHAN, grande imprensa e agências de turismo.

Tomamos estruturas de significado enquanto elaborações lógicas construídas histórica e socialmente, mais ou menos cristalizadas em pessoas e instituições, mas que são manipuladas de diferentes formas diante de demandas e experiências concretas. Portanto, essas estruturas, de um lado, determinam os discursos dos agentes e atores sociais, circunscrevendo dentro de um sistema de significações os bens imóveis (igrejas, peças sacras, etc.) e os eventos realizados a partir deles (procissões, devoções, concertos musicais, visitas turísticas e explanações didáticas); de outro lado, elas estão sendo constantemente ativadas pelos agentes e atores sociais em jogo, para dar sentido a objetos e rituais, em função de seus interesses e posição dentro do sistema social.

Embora esteja claro para nós que essas estruturas não são excludentes nem impermeáveis, mas se dão em um "gradiente de circulação" (Sanchis, 1983), possibilitando combinações diversas, tanto no plano dos significados quanto no das ações concretas, para efeito deste artigo gostaríamos de apresentar em destaque cada uma dessas matrizes geradoras de significados, instituições, agentes e práticas. Em outros textos dessa mesma pesqui- 
sa, esta perspectiva mais ampla e articulada é desenvolvida ${ }^{1}$. Neste artigo, todavia, mesmo sob o risco de um certo esquematismo, ao expormos cada estrutura desde sua origem e ponto de vista, esperamos ganhar em profundidade e complexidade, o que nos permitirá antever os desdobramentos dos embates, negociações e combinações entabuladas pelos agentes e atores nesta arena de disputas e conciliação que é a Semana Santa em Tiradentes.

A primeira matriz é a religião, que se compõe de duas vertentes. A primeira, a Igreja Católica, que se legitima através do fornecimento do mito, expresso no Evangelho, e através disso afirma seu poder enquanto instituição revestida de representação divina. Apesar dessa condição privilegiada, enfrenta contradições internas, com as irmandades religiosas locais, e contradições externas, com instâncias laicas do patrimônio histórico e do turismo, que tencionam dar outros usos à arquitetura sacra da cidade. A segunda vertente se compõe do povo católico tradicional da cidade, que através de suas irmandades, vivencia e reafirma o sentido religioso tradicional familiar. Esse sentido passa pelas relações privadas, de vizinhança, de continuidade atávica com a religiosidade de seus pais, sempre atualizadas pelos rituais e obrigações em torno das imagens dos santos padroeiros em seus adros, capelas e igrejas de Tiradentes. Aqui, também se verificam contradições em relação a outros segmentos da população local, mais modernizados e abertos à penetração de outros significados e usos de caráter cultural e econômico para espaços e objetos religiosos.

A segunda matriz, é a do patrimônio histórico e cultural, oriundo de um poder estatal como também de grandes conglomerados empresariais, exteriores à realidade local. Este se expressa em instituições ligadas à preservação do acervo histórico e cultural local, que se legitimam através de um conhecimento e intervenção de cunho técnico e que ativam um sentido histórico, da memória, visando a sedimentação de uma identidade cultural, local e nacional.

A terceira matriz é a do turismo, que introjetada, também, de fora, por forças econômicas e políticas interessadas no "desenvolvimento e integração regional", introduz uma nova forma de visualizar os bens de origem sagrada, secularizando-os enquanto objetos de consumo, em última instância, voltados para o lazer do turista.

\footnotetext{
1 Particularmente o artigo Cidade Presépio em tempo de Paixão. Turismo e religião: tensão,
} negociação e inversão na cidade histórica de Tiradentes (Giovannini, 2001). 
Passaremos, em seguida, a examinar cada uma delas enquanto projetos, discursos, produções teóricas, revestidas numa estrutura de significados que se presentifica e é acionada por agentes e instituições tanto locais e provincianas quanto (trans)nacionais.

\section{Religião}

Figuram como agentes e atores sociais dessa dimensão e produtores dos discursos que a constituem: o pároco da Matriz, outros sacerdotes e seminaristas, lideranças leigas das irmandades locais e os fiéis. A questão de fundo que os envolve diz respeito ao uso das igrejas, imagens e objetos sacros e o sentido produzido nessa relação. O sentido predominante é o do sagrado, embora possa haver divergências entre os atores sobre a extensão da correspondência entre sagrado e as igrejas, suas imagens e objetos.

Dentre as narrativas que compõem o discurso do sagrado em face de seus objetos, sobressai-se a do mito da Paixão. Talvez esta evidência devase ao fato da pesquisa ter sido realizada na Semana Santa; todavia, convém lembrar o caráter fundante desse mito para o catolicismo, sendo sua rememoração o rito mais importante do seu calendário litúrgico, principalmente em lugares marcados pelo catolicismo tradicional, como Tiradentes. Constatamos na experiência do sagrado vivida pelos católicos tiradentinos a centralidade da referência discursiva e dramatúrgica ao mito.

Por fim, é importante ressaltar o caráter social com que se reveste a religião. Ela se expressa numa rede de relações que vai da família, passando pela irmandade e pela paróquia, até extrapolar a realidade empírica através de um imaginário que remete o crente a um outro plano onde se encontram seus antepassados, os santos e o próprio Deus. Aqui estamos no terreno do que a Escola Sociológica Francesa chamou de representações coletivas, como também das relações de reciprocidade enquanto constitutivas do social. Nesse sentido, concordamos com Marcel Mauss (1974) na interpretação do nosso objeto, de que a relação do fiel com o santo, a Virgem e Deus, baseada na oferta do sacrifício, no pedido de graças e milagre e a conseqüente retribuição de devoção e homenagem, alinhava essas crenças e práticas ao segmento social em questão. 


\section{0 sentido do sagrado}

As práticas discursivas dos sermões proferidos pelos padres e as encenações organizadas pela irmandade, realizadas na Semana Santa em Tiradentes, buscam enfatizar a centralidade do sagrado, expresso no mito da Paixão, em meio a uma pluralidade de discursos e eventos que ocorrem na cidade durante esse feriado turístico. Na fala do pároco e dos religiosos, o esforço de marcar uma distinção em relação ao turismo é evidente. Este é classificado como profano e portador, por contraste, de um sentido ameaçador ao religioso que pretendem consagrar. Diz o padre:

Ultimamente tenho feito uma campanha aqui em Tiradentes com as pessoas que participam da igreja, das missas, pra ter um cuidado muito grande para não esvaziar o sagrado. Devido ao mundo materialista de hoje que só pensa em dinheiro. Aqui em Tiradentes só pensa em atrair turista e que a cidade fica cheia de turista o dia todo, mas... Então a primeira coisa é pensar no sagrado, o profano é segundo, terceiro lugar. Então isso aí tem tido um atrito muito grande. Quem pensa só no turismo, no ganhar dinheiro, e escuta isso, acha ruim. Eu posso falar isso, eu tenho o respaldo do povo, porque eu falo para o povo. Olha este lugar aqui é sagrado, a igreja foi feita há quase trezentos anos atrás, não é pra fazer concerto, isso é teatro que faz.

A despeito desse discurso sacralizador, sabe-se que tanto a igreja da Matriz quanto a do Rosário e a do Bom Jesus são utilizadas, sob autorização do padre, para exposições de arte e concertos musicais. Indagado sobre isso, ele alega que muitas vezes, dependendo da situação, não há problema algum, afinal, é importante não radicalizar as opiniões, sob o risco de "fanatizar":

O concerto é feito no Vaticano, em diversas catedrais do mundo. Porque um concerto com música sacra, um concerto de orgão, de piano, não agride [...] Mas aqui já chegou uma época que nós permitimos fazer concerto e teve gente que fumou lá dentro da igreja, turista, pessoa que vê a igreja como uma casa qualquer.

O depoimento do pároco é atravessado por ambigüidades, que, no entanto, não parecem contraditar o sentido totalizante do primado do sagrado. 
Significados como o de sagrado e profano são acionados na construção do esquema imperante, mas podem variar de acordo com as situações e posições em jogo. Como encontramos em Lévi-Strauss, o xamã nambiquara pode voar nas asas do trovão ou fazer negociações políticas com a tribo vizinha ao mesmo tempo (1991, p. 198). Da mesma forma, o padre pode falar nos sermões que é profano um concerto em uma igreja, mas permitilo, se não for agressivo, e angariar recursos para a paróquia, transitando do nível da adesão para o nível da flexibilidade, dependendo da situação em que se encontra.

O discurso sobre a necessidade de se garantir o sentido sagrado das igrejas e seus objetos vem se intensificando à medida que surgem na cidade alternativas concorrentes para o uso desses prédios, movidos por interesses culturais e econômicos. O choque de visões de mundo parece se acentuar, na medida em que são os próprios católicos do lugar que pressionam o padre a garantir um sentido sagrado para esse patrimônio de valor atávico, agora ameaçado de se transformar em outra coisa. O padre, por sua vez, percebe que para manter sua autoridade e influência junto aos fiéis terá que responder a essa demanda de sagrado do seu rebanho. Mas será que ele está preparado para esse embate? A Igreja Católica de maneira geral, não vem instrumentalizando seus representantes para o enfrentamento dessas questões, uma vez que não existe, por parte de sua hierarquia, diretrizes para as paróquias que vivenciam esses problemas. Isso de dá, talvez, porque na cultura católica Pós-Vaticano II o sagrado não esteja tanto em peças de madeira ou em igrejas antigas. Dessa forma, o sentido de um sagrado cristalizado nas edificações e imagens do catolicismo colonial dessa Minas barroca está resguardado principalmente nas manifestações e crenças dos habitantes católicos tradicionais de Tiradentes, mais do que na própria Igreja-Instituição. Em meio a uma Igreja hesitante, através de seus quadros locais (párocos, padres), porque comprometida com as injunções da modernidade, vem dos católicos tradicionais o impulso para a manutenção de um sagrado totalizador e intransigente quanto ao uso de objetos que, de tão longa data, já são do domínio das "coisas santas".

Mas fica uma questão: por que o povo católico tradicional do lugar, que se indispõe com a iniciativa das exposições de arte e concertos musicais dentro das igrejas, nas suas procissões da Semana Santa, não se esquiva de compatibilizar arte e música com religião? Nesse caso as procissões funcionam como grandes encenações, cercadas de bandas de música e coral 
entoando música barroca. Será porque no caso dos concertos e exposições dentro das igrejas, o centro é o evento turístico, e não o religioso? Será porque é cobrado ingresso? Pensamos que a dificuldade de aceitação, reside no caráter exterior que assumem as manifestações artísticas e culturais em relação ao caldo de cultura religioso primevo da tradição colonial onde arte, mito e sociabilidade se encontravam imbricados e faziam sentido sob a égide do sagrado.

\section{Mito da Paixão}

Para o católico tiradentino, o mito da Paixão se constitui em elemento estruturante de sua vivência religiosa. As imagens sacras nas igrejas, a música barroca e a própria tradição das procissões do Senhor Morto, dos Passos (Via Sacra), do Enterro, etc., na Semana Santa funcionam como elementos da estrutura de significação que reativa e reatualiza o mito. A narrativa desse mito atravessa o conjunto dos sermões proferidos nas missas e cerimônias religiosas como uma exigência dos fiéis, que se reconhecem mais nessas narrativas que nos temas sociais ligados à Campanha da Fraternidade.

Este mito, que reconta fatos $a b$ origine, revive no fiel imagens e potências daqueles tempos inauguradores, identificando-o com essa história fundante (Eliade, 1972). Nas procissões da Semana Santa, encenação e locução se combinam, produzindo um sentimento de identificação do fiel com as imagens do Cristo flagelado e morto. O sacerdote, como um narrador, vai discorrendo sobre o que os personagens estão encenando na prisão de Jesus, na Santa Ceia ou na sua morte na cruz. Também no ritual intitulado Descendimento da Cruz, imagem e voz se articulam na produção de significado, quando uma imagem de Cristo, com pernas e braços articulados, é desprendida da cruz em que estava fixada e o sacerdote vai comentando sobre cada chaga correspondente ao pé e mão desprendida como expressão do sofrimento de Jesus pelos homens. Nessa etapa do ritual, é experimentado pelo fiel um processo de identificação com Jesus sofredor, através do ato de presenciar a "realidade viva" de seu martírio. Através da participação nos eventos da Semana Santa: procissões, encenações, no ato de carregar o andor com a imagem de Jesus, Senhor dos Passos e de Nossa Senhora das Dores, o tiradentino é conduzido a esse tempo mítico, o tempo de Jesus e do seu sofrimento, estabelecendo uma continuidade entre o mundo do mito 
e a realidade cotidiana desses fiéis. Além dessa identificação, ocorre também uma projeção dos sofrimentos e vicissitudes desse homem e mulher comuns no sofrimento maior do Cristo, assim como uma substituição do seu sacrifício cotidiano e do seu sacrifício ritual (como carregar o pesado andor) pelo sacrifício redentor incomparável de Jesus, Filho de Deus, que morre pelos homens, que pela sua magnitude garante uma eficácia salvífica, doadora da graça e do milagre às promessas e demandas desses fiéis sacrificantes humanos. Esta reciprocidade de dom e contradom extrapola os marcos do interesse ou de uma projeção num plano simbólico, de relações sociais de dependência entre um protetor e seus agregados, como que quiseram algumas análises (Zaluar, 1974, p. 78-98). Diz respeito, sim, a uma reciprocidade que extrapola a dimensão das coisas tangíveis para penetrar na esfera das significações. Através dessa "cascata de sacrifícios", termina por separar os oficiantes do "mundo das coisas", inserindo-os na ordem do sublime, como afirmou Bataille (1975, p. 37), como também "recordam a realidade do virtual ou do possível em uma ordem estabelecida que parece ignorá-lo", nos dizeres de Duvignaud (1983, p. 90-91).

\section{Patrimônio histórico e cultural}

Sem querer uma definição rigorosa de patrimônio cultural, sabe-se que sua significação vocabular aponta para aquilo que é de herança comum. $\mathrm{Na}$ região estudada, através do trabalho de intelectuais e técnicos ligados ao Instituto do Patrimônio Histórico e Artístico Nacional (IPHAN), forjou-se um conceito de patrimônio cultural capaz de fornecer às pessoas uma referência intelectual para se pensar as igrejas, celebrações e imagens de uma outra forma que não fosse somente a religiosa, mas histórica e cultural, assim como esses objetos e eventos como portadores de uma identidade, seja ela local e/ou nacional.

Em entrevista com a diretora do IPHAN em Tiradentes, ela afirmava ser objetivo da instituição no local a preservação do patrimônio, entendendo este, "no sentido mais amplo da palavra [...] pegando até o patrimônio imaterial, tudo o que diz respeito ao patrimônio artístico e cultural". Sendo a missão do instituto, "identificar, proteger e conservar" esse patrimônio (Magalhães, 1984, p. 40). O discurso produzido nos marcos do instituto se caracteriza por seu estilo técnico. A diretora do IPHAN em Tiradentes 
chamava atenção para um grande conjunto de informações disponíveis no instituto e para a presença de um

corpo técnico altamente qualificado e multidisciplinar, onde você tem profissionais com alta qualificação técnica que podem estar sempre colaborando no sentido de preservar e conservar este patrimônio como um todo e exercer uma fiscalização sobre ele.

Fonte interessante para se observar esse discurso técnico sobre os prédios e objetos sacros de Tiradentes são as revistas e boletins do IPHAN: Notícias do Patrimônio, Boletim Informativo do Patrimônio e Informativo do Ministério da Cultura. Desponta nesses textos sobre as igrejas e a arte sacra um tom técnico e sóbrio, denotando um jargão que se observa em outras áreas do conhecimento com alto grau de especialização, como, por exemplo, a economia e seu "economês". Não se reportam à questão religiosa nem a qualquer envolvimento decorrente disso, tampouco fazem apelos turísticos. A identificação de traços históricos e culturais nas peças, imagens e monumentos sacros visa o desvelamento de uma essência identitária que possa forjar um ideal de cultura regional ou nacional, de um marco que perdura ao longo dos anos de forma coerente e, portanto, justifica a sua preservação. A conservação do acervo é feita de um ponto de vista estritamente técnico, e para tal utilizam-se de articulações com as comunidades locais e grupos políticos, na busca de verbas para seu projeto de conservação. Eis um exemplo do teor tecnicista do discurso em um trecho de uma matéria do Boletim do IPHAN, de junho/julho de 2000:

Forro da Igreja do Bom Jesus do Matosinhos em Restauração. Com projeto e supervisão técnica da $13^{\circ} \mathrm{SR}$, e recursos destinados pela UNESCO, no valor aproximado de R \$ 60 mil, estão sendo realizados trabalhos de restauração no forro da Igreja do Bom Jesus de Matosinhos, de Congonhas. O forro da nave onde encontra-se pintura de João Nepomuceno Correia e Castro, datada de fins do século XVIII, cobrindo área de $140 \mathrm{~m}^{2}$, encontrava-se em acentuado estado de deterioração [...] A policromia apresentava sujidades generalizadas [...] foram realizados inicialmente a proteção dos retábulos [...] E a restauração constou da refixação da policromia, utilizando-se adesivo adequado à técnica da pintura. 
Observando as notícias expressas nesses boletins confirma-se a preferência existente pela conservação de prédios religiosos da religião católica, como também de monumentos civis, prédios públicos e imóveis onde residiram personalidades pertencentes às elites da época. Apesar de raras exceções, a maciça maioria dos textos e fotos que figuram nessas publicações é de templos e arte sacra católicos. O reconhecimento pelo IPHAN de que os templos e a arte católica são o que há de representativo no campo religioso em termos de patrimônio é uma evidência e recorrência pelo menos no que tange a Minas Gerais. No mesmo boletim, citado acima, encontrase a notícia da celebração de uma missa pelo bispo de Mariana, abrindo as comemorações pela restauração da Igreja do Carmo, incendiada há poucos anos.

Dessa forma, cabe destacar da concepção do IPHAN acerca do que seja patrimônio cultural, primeiro, a abordagem técnica com que são tratados os imóveis e objetos religiosos locais. Segundo, a despeito da separação estabelecida entre o caráter religioso e a visão histórica e cultural com que esse patrimônio é tratado pelo IPHAN, não deixa de haver aproximações e acordos entre essa instituição de defesa e conservação do patrimônio com as instituições religiosas, proprietárias dos mesmos. Terceiro, a identificação desse complexo de devoções populares como expressão de uma "identidade" regional e/ou nacional. Quarto, essa identificação passa pela ampliação do conceito de patrimônio, incluindo não somente prédios e objetos, mas também cerimônias e festas. Assim, as devoções, os rituais, as celebrações da religiosidade católica tradicional de Tiradentes, no entendimento do IPHAN, devem ser preservados para serem vistos e experienciados como expressão de uma identidade nacional, que se estende a todos aqueles que visitam a cidade, na qualidade de turistas.

\section{Iurismo}

A cidade de Tiradentes oferece uma série diversificada de atrativos turísticos. O patrimônio arquitetônico, a Serra de São José com suas cachoeiras, a culinária, as festas e os festivais, cada um deles atrai um público diferenciado. O recorte que aqui realizamos enfoca o turismo realizado no período da Semana Santa. Para aprofundarmos nossa tipologia sobre esse turista que se desloca para a cidade nessa época, compararemos os dados 
levantados por nós no período desse feriado religioso em 2000 e 2001 com outros dois levantamentos, um realizado pelo SEBRAE em julho de 1996, e outro por Pellegrini no período de fevereiro a março de 2000, abrangendo o Carnaval. Como primeira constatação recorrente nas três pesquisas, observa-se que o turista que visita Tiradentes na atualidade provém de várias partes do país, principalmente de São Paulo, Rio de Janeiro e Belo Horizonte, capitais mais próximas. É consenso nas três fontes que a maioria desses turistas são provenientes da Região Sudeste. Se em julho de 1996 e em janeiro de 2000 a maioria dos visitantes vinham do próprio Estado de Minas Gerais, constatamos que na Semana Santa a maior parte veio do Rio de Janeiro (30\%), de São Paulo (25\%) e de Minas Gerais (18\%). O grupo que mais visita a cidade, permanece mais dias e participa dos eventos está na faixa de 30 a 40 anos, possui uma renda de média a elevada e sua faixa educacional se situa no nível superior. Possuem uma formação cultural apurada, quase erudita, no sentido de praticarem leitura regular e valorizarem a história e a arte como hábitos.

Se, por um lado, é notória a motivação do lazer e do consumo por parte desses turistas na sua estada em Tiradentes, constata-se, também, que esse lazer passa pela cultura e por uma busca de conhecimento, aliado a uma experiência estética que exercitam na contemplação de monumentos, igrejas ou nas visitas a ateliês e lojas de arte. Entrevistando os viajantes, pode-se constatar que, apesar das variações e ênfases, o objeto do seu interesse é uma fruição do conjunto das particularidades da cidade, enfeixados em uma totalidade, uma temática. A menção aos atrativos da cidade revela sempre uma listagem de elementos articulados: bares, restaurantes, lojas, ateliês, igrejas e cerimônias rituais. Os depoimentos apontam sempre para a associação dessas dimensões: "estilo arquitetônico, preservação da história, da religião e dos costumes", "beleza arquitetônica carregada de história". Enfim, se quisermos uma definição mais generalizada, a idéia que se destaca entre os turistas é de fruir uma "ambientação... uma atmosfera", muitas vezes uma atmosfera histórica, "dos séculos XVIII e XIX". O importante é estar em Tiradentes, andar por Tiradentes, consumir a cidade, o conjunto, o clima, o "chique" de Tiradentes: "Adoro andar por toda Tiradentes", nos disse um grupo de turistas.

No Festival de Cinema da cidade, em janeiro, também se percebe esse sentido de conjunto. Dizem ser uma das melhores mostras de cinema do circuito nacional, pois oferece um ambiente de cenário e, sendo um lugar 
pequeno, todos podem se encontrar com facilidade. A possibilidade, aí expressa, de encapsular todo um mundo que ali se encontra de uma só vez, é como se sentir frente a uma "cidade-presépio", diante da qual o apreciador tem a impressão de tê-la todas nas mãos, num sentimento de totalidade e harmonia. Se os prédios, ruas e monumentos dos séculos XVIII e XIX formam a referência espacial, é a tradição do povo com sua arte e suas festas que dá a esse cenário a alma viva, capaz de despertar emoções mais profundas, garantindo uma experiência que une passado e presente, memória e afetividade. Se o lazer, evidenciado na frequiência a bares, restaurantes e pousadas confortáveis é um componente forte da motivação para viajar a Tiradentes, o conjunto arquitetônico é o cenário que interage e proporciona o pano de fundo para as experiências subjetivas nos turistas.

Diante desse complexo de experiências, perguntamo-nos, então, como o turista que visita Tiradentes na Semana Santa construiu em seu imaginário uma afinidade e pertença a este conjunto de culturas material e imaterial, associado a um estilo moderno de lazer e conforto que envolve os equipamentos turísticos da cidade? Para responder a essa questão, procuraremos focar algumas emoções e percepções dos turistas que remetem a temas ou categorias que podem nos ajudar numa interpretação do fenômeno.

A primeira delas remete à questão da memória. As celebrações da Semana Santa despertam, em muitos turistas, lembranças de tempos da infância passados em uma cidadezinha do interior na qual o indivíduo foi criado antes de ir para uma cidade grande, ou de vivências religiosas que experimentou em um tempo remoto. Segundo alguns depoimentos, as procissões evocam um passado nostálgico e significativo na sua formação enquanto indivíduo: "já segui procissões e fui devoto quando criança. É um tempo de boas recordações [...] época de minha infância". Esses depoimentos nos levam a crer que estar em Tiradentes na Semana Santa e participar de rituais religiosos tradicionais é rememorar uma história de vivência religiosa familiar.

No nosso entender, esse sentimento que se inicia saudosista, através do reconhecimento de uma realidade que o indivíduo partilhava quando criança, desdobra-se para uma constatação de que essa realidade, da qual ele não mais partilha, no entanto, ainda perdura na crença dos nativos dessa pequena cidade interiorana, e ao atribuir um valor cultural a essas manifestações, enquanto algo genuíno e da tradição do nosso país, promovem um reencontro com seu passado em novas bases. 
No geral, a religião católica é vista pelos turistas com reservas e críticas, porém tais críticas se referem principalmente à dependência ou às imposições institucionais imperantes no catolicismo com relação a vivência de uma religiosidade. Nos depoimentos, defendem a religião como dimensão vivida pelo indivíduo e que a mediação e controle institucional é algo desnecessário para realizar experiências e valores que irão reger seus comportamentos. A concepção de religião desse turista que visita Tiradentes segue uma tendência contemporânea de individualização da crença e liberação institucional, realidade analisada atualmente como o comportamento religioso dos tempos da globalização e (pós) modernidade (Hervieu-Léger, 1996; Pace, 1997). Para estes turistas, o sublime se "encontra disperso e disponível em todo e qualquer lugar, o sagrado encontra-se livre de qualquer monopólio". Em outro depoimento:

Para mim, religião é respeitar o universo e compreender que fazemos parte de um todo. Jesus é a energia que tem o poder de equilibrar este todo. Não tenho nenhuma devoção, procuro agir em busca deste equilíbrio.

Perguntamos, então, por que esses turistas movidos por concepções tão fluidas, abstratas e subjetivas de religiosidade, se mobilizam na visita a igrejas barrocas e no acompanhamento de procissões onde se cultua a imagem do filho de Deus, carregada em um andor, com um envolvimento sacrificial considerável? Para Brandão, o turista não tem nenhum interesse propriamente religioso quando visita as igrejas coloniais:

[...] o que se busca entre as igrejas que valem mais como museus ou monumentos é uma espécie rara e diversa de cultura que como eventos, lugar ou objeto acredita-se que tenha preservado os valores e os símbolos de nossa história. Uma cultura guardiã, portanto, de nossa própria identidade nacional. (Brandão, 1989, p. 4).

Insistimos, no entanto, na pergunta, por que escolher as igrejas barrocas e as procissões do catolicismo popular tradicional como expressão dessa "identidade nacional"? Pensamos que a escolha destes bens passa, sim, por uma representação de "nação" elaborada por estes indivíduos modernos que visitam as cidades históricas, e que isso é central no seu imaginário, como 
já discutimos no item do patrimônio histórico e cultural e ainda discutiremos no próximo tópico deste texto; entretanto, consideramos também que esta representação, para um número representativo deles, vem mediada por um aspecto subjetivo, emocional e vivencial que faz dessa experiência algo mais do que o gozo de um espetáculo ou de um aprendizado de conteúdos históricos.

Em conversa com uma jornalista, em janeiro de 2000, que visitava a cidade para uma atividade de oficina de cinema, sentada no adro da igreja, ela comentava a respeito da sensação que lhe causava o interior dessa igreja barroca. O que a impactava era visitar as igrejas de Tiradentes, e isto foi motivado por uma primeira visita que fez, acompanhada de um guia que ela percebeu como um "missionário" que "pregava" para ela, e isso a emocionou. Conta que se deteve diante de uma tela com o Cristo crucificado, na parte lateral da igreja, e constatou que o rosto da imagem era negro; como o guia também era negro, aquilo evocou a questão da escravidão e todo seu imenso peso social e moral com que impregnou desde os tempos coloniais a nossa história, e era essa história viva com seu drama e redenção que estava expressa naquela obra de arte. Perguntada se ela se emocionava pelo significado ou pela arte em sua manifestação estética, ela respondeu: "Pelo significado. Não gosto muito da arte barroca, é muito forte, dramática, muito sofrimento, muito confuso...". Perguntada se acreditava em Deus, respondeu: "Muito! Já fui marxista, atéia e existencialista. Lia Sartre [...] hoje vejo diferente. Acredito em Deus, que pode ser muitas coisas... para mim é o sentido da vida e do mundo". Perguntada se, quando sentiu que havia experienciado o sentido profundo daquela tela com o Cristo de rosto negro, aquilo fora um sentimento religioso, ela disse "sim, naquele momento senti a presença de Deus!".

Dessa forma, mesmo sem uma motivação inicial religiosa, o contato do indivíduo com as imagens e arte sacra barroca das igrejas de Tiradentes pode desencadear nele outras estruturas de significado, deslocando as representações imaginadas do terreno histórico, artístico e cultural para a região do mistério, fazendo-o experimentar o sagrado em sua forma de tremendum e fascinium (Otto, 1955).

Uma turista dizia que entrar na Matriz era como entrar em um outro mundo transcendente. Sua maior riqueza, que não existe na igreja do Bonfim e na de São Francisco em Salvador, cheias de riqueza e soberba, é que na Matriz há um chamamento para o transcendente. Perguntada se o motivo dessa chamada era a arte, ela respondeu: 
Por causa da expressão... Arte tem no mundo inteiro, mas expressar o transcendente desta forma é muito difícil. Daria para passar uma vida aqui dentro, cada detalhe... Eles [os artistas] tocam o transcendente... O transcendente os toca e o Espírito Santo estava com eles e ainda está; senão não durava tanto tempo sua expressão.

Percebe-se como ela vai da arte para o sagrado, quando afirma o envolvimento na transcendência que os artistas tiveram ao esculpir as talhas, e, por outro lado, como ela vai do transcendente para a história, responsabilizando o Espírito Santo por conservar ao longo dos tempos, num movimento de historicidade, o sopro de expressão cristalizado na obra pelos seus criadores naquele momento primevo. Historiciza o transcendente e sacraliza o contigente.

Uma garota portuguesa confessava que de ver tantos santos de roca, talhados na madeira, com cabelos reais e com expressões fortes e marcantes, teve pesadelos durante a noite. Sonhou que sua mãe estava morta e em volta dela todos aqueles santos. A lembrança da mãe, o medo, o mistério da morte estavam em seu sonho. Isso é, de alguma forma, uma experiência religiosa!

Poderíamos nos perder na quantidade de depoimentos que colhemos nesse sentido, na quantidade de expressões que observamos, emoções, choros e risos, admiração e medo diante das formas barrocas ou a sensação de transcendência e presença de "algo maior". De outro lado, também não foram poucos os risos de deboche ou as interpretações puramente racionais, que nos levam a concordar com Brandão, pelo menos nesses casos, que as "igrejas históricas esvaziam-se das rotinas religiosas enquanto recuperam símbolos e objetos artísticos e arquitetônicos de um passado de lugar de religião como espetáculo de cultura" (Brandão, 1989, p. 60). Muitos visitantes guardam um respeito silencioso diante das imagens sacras, mas não tratam o ambiente como sagrado. Muitos turistas se posicionam em face das procissões como uma platéia de espectadores assistindo a um desfile, como em qualquer evento cultural.

O turista vivencia o contato com uma tradição religiosa - tanto na realização de uma experiência mística ou na falta desta - mas quase sempre incorporando a noção de história e cultura, expressas na idéia de "identidade nacional". Mesmo os mais fervorosos sempre consideram a dimensão histórica incrustrada nas igrejas e rituais. No caso da jornalista, ainda que 
tivesse tido uma "experiência mística", esta foi atravessada por reflexões racionais e modernas: a história de Minas colonial e o sofrimento da população escrava negra. Ao se emocionar e sentir a presença de Deus na visão do Cristo negro, mostrada por um guia negro, ela articulou consciência histórica, identidade brasileira e experiência do sagrado.

É interessante notar que dos 100 questionários que aplicamos aos turistas frequientadores das igrejas barrocas durante a Semana Santa, quando se perguntava sobre a importância daquelas igrejas $58 \%$ reputaram a causa ao seu aspecto histórico e artístico, contra $6 \%$ que afirmaram sua importância prioritariamente religiosa. No entanto, $35 \%$ afirmam que sua importância é histórica, artística e religiosa, sem prioridades. Assim, cremos poder constatar que a dimensão místico-religiosa é variável na percepção dos turistas, ao passo que a esfera da história e da arte está sempre presente nas concepções deles, como um dado constitutivo do papel representado por esse conjunto barroco religioso. Dificilmente um turista, mesmo um religioso, padre ou freira, entra em uma dessas igrejas somente para orar, nesses dias de feriado. A idéia de patrimônio histórico e cultural se encontra presente, às vezes mais determinante que a idéia do sagrado. Já observamos padres e freiras andando pelos templos constatando seus aspectos históricos e artísticos e até interpretando, dentro de uma chave hermenêutica, os símbolos bíblicos incrustados na sua arquitetura, ou contextualizando determinado estilo ou costume da história da igreja, expresso numa escultura, imagem ou obra de arte, tudo isso sem se preocuparem com orações e genuflexões.

\section{0 "olhar exótico", ou o olhar turístico como "máquina de produzir a diferença"}

Se o tema do uso das igrejas como espaço para exposições de arte e concertos musicais é controverso entre os nativos de Tiradentes, entre os turistas é quase unânime a sua aceitação. Consideram que o ambiente das igrejas é compatível com uma atividade cultural, pois essa ambientação pode produzir um clima propício ao desenvolvimento da arte. Diz um turista: "Adorei o concerto barroco em uma igreja barroca. Ouvir Bach em uma igreja barroca é como ouvir bossa nova em Ipanema ou jazz em Nova Orleans". Aqui se pode constatar entre os turistas, num primeiro plano, um reconhecimento da singularidade desses templos enquanto de caráter estri- 
tamente religioso; todavia, num segundo plano, acrescentam-lhes um caráter universal e cosmopolita que ultrapassa essa concretude local, através de uma experiência estética e cultural.

Por outro lado, assiste-se entre os turistas uma compatibilização entre a esfera local e suas expectativas universalistas, quando encaram a religiosidade tradicional do lugar como fonte de autenticidade, espaço telúrico, de "raiz" da cultura nacional. Na fala de um turista: "A tradição é algo fundamental para se evitar a decadência de uma sociedade". Se esta categoria, "memória nacional", já foi criticada na literatura antropológica como algo "fabricado" a posteriori para dar a impressão de unidade de uma totalidade, que na verdade é diversificada (Gonçalves, 1996; Ortiz, 1980a, p. 61), porém, o que para nós parece interessante, no caso, é que é através da ressignificação da chamada tradição popular dos nativos que a experiência do turista, indivíduo cosmopolita, ganha densidade e sentido. A idéia de "cultura popular", projetada como expressão nacional, nos interessa aqui apenas enquanto um significante, ao qual são acrescentados, pelos turistas, significados relacionados às suas expectativas subjetivas, intelectuais e estéticas. Como caso exemplar, observamos uma conversa entre um turista, um engenheiro químico que trabalhava na Petrobrás e vivia mais no exterior que no Brasil, e um senhor de uns 86 anos, tiradentino e lavrador aposentado. A conversa versava sobre os ramos de arnica, que eram mostrados pelo lavrador ao engenheiro como uma planta que ornamenta as igrejas nas festas da Quaresma, mas também remédio de medicina caseira para tratamento de hematomas. Dizia o velho que nunca tomara outro remédio, e que esse era de sua horta, conhecimento que passava de pai para filho. Concordava o engenheiro, acrescentando que essas práticas deveriam ser preservadas, pois o país estava sendo invadido por remédios estrangeiros. O significado emprestado pelo turista a essa planta remete a relações do Brasil com empresas farmacêuticas multinacionais e à consciência ecológica, temas que não preocupam a noção atávica e pessoalizada do uso da planta pelo lavrador. $\mathrm{Na}$ tentativa de compreender um ao outro, pode-se cair em mal-entendidos, que entretanto podem ser produtivos na medida em que satisfazem a necessidade de construção de suas próprias identidades, mesmo que olhando o outro, de modo enviesado, terminem por projetar um olhar sobre si mesmo.

Em geral, o tratamento que a imprensa das grandes cidades dá ao tema do turismo nas "cidades históricas", inclusive Tiradentes, vende a imagem de algo exótico que pode ser usufruído e consumido, resvalando muitas vezes 
para uma descrição caricata da realidade. No entanto, a resultante entre o contato do turista com a imagem desta alteridade, muitas vezes idealizada por ele, se constitui como fonte de novos significados, imagens e identidades.

O jornal Tribuna de Minas, de Juiz de Fora, do dia 5 de abril de 2000, em seu caderno semanal de turismo, trouxe uma reportagem sobre a Semana Santa em Minas Gerais, dentro de uma série dedicada ao turismo para locais e eventos religiosos em várias partes do Brasil e do mundo. $\mathrm{O}$ fascículo em questão trazia a seguinte manchete: "Semana Santa. Tradição preservada em Minas - ruas de pedras decoradas e janelas enfeitadas com toalhas bordadas para as procissões mudam a paisagem das cidades históricas"; em seu texto podia-se ler:

A religiosidade de Minas Gerais faz da Semana Santa uma das épocas mais interessantes para visitar as cidades históricas. Em São João Del Rei, Tiradentes, Ouro Preto e Mariana, a programação dos dias santos oferece cerimônias emocionantes que convidam à participação e reflexão. São missas, procissões e encenações que enchem de vida as igrejas barrocas e as típicas ladeiras de pedra. O casario colonial ganha uma dose a mais de beleza com as decorações feitas pelos moradores. As janelas ornamentadas com toalhas bordadas, com motivos que remetem à Páscoa, conferem cores novas à paisagem.

A fé do nativo da localidade se transforma em produto típico, que dentro de um ambiente turístico é objeto de consumo, fazendo também o visitante entrar em contato com uma concepção de sagrado singular e própria de culturas diferentes da sua.

Uma das características desse discurso proveniente de instâncias ligadas à imprensa e ao turismo é a não separação das dimensões da história, religiosidade, estética e lazer, articulados em uma totalidade que garante a eficácia desse discurso. O turista tem a garantia de comprar um pacote completo, viaja de trem ao passado, se emociona com as cerimônias, se encanta com a beleza estética das igrejas e ainda pode ir a um bom restaurante degustar um bom vinho, com direito à escolha de uma culinária mineira, italiana, francesa ou chinesa. Os jornais "vendem" ao turista o projeto de consumir a cidade de Tiradentes como conjunto, com a possibilidade de estabelecer uma composição de estruturas de significado do mito, da história, da cultura, da estética e do lazer, com o privilégio de estar tendo essa experiência em uma "roça globalizada". 
Chega a ser explícita, na oferta do "pacote", a promessa dessa experiência totalizante:

Além de participar e se emocionar com os eventos religiosos da Semana Santa em Minas Gerais, é possível hospedar-se em hotéis e pousadas que remetem ao Brasil colônia. Instalados em casarões e sobrados, preservam a arquitetura, a decoração e o típico café da manhã, farto em pães e bolos, queijos e geléias. A sensação é de se estar em pleno século XVIII. Nas ruas, os museus e as igrejas contam a história dos ricos tempos do ciclo de Ouro. Através das obras de Aleijadinho e das pinturas de Ataíde aprecia-se toda a suntuosidade da arte barroca. (Tribuna de Minas, 2000).

O apelo "romântico" fica bem evidente nesta matéria, um romantismo que se traduz pelo seu sentido de valorização de uma tradição, de um retorno imaginário a uma época idealizada:

O casario colorido, a magnífica Matriz de Santo Antônio e as várias igrejas e capelas conspiram contra a modernidade. O núcleo histórico é retrato vivo da integridade colonial... Exemplar preservado das antigas cidades mineiras, Tiradentes parece saída de um túnel do tempo. (Tribuna de Minas, 1998, p. 27).

É interessante notar que o projeto gráfico dessas reportagens dá possibilidade ao leitor, pouco interessado na complexidade e nos meandros do desenvolvimento histórico e da cultura barroca, acompanhar as reportagens através de imagens, fotos em cores vivas e dizeres resumidos. Essas imagens e slogans podem ser consumidos de uma forma mais facilitada:

A pacata cidade de Tiradentes, um dos menores municípios mineiros, não sofreu os efeitos colaterais do progresso. Passear pelas ruas de Tiradentes é imergir na história, admirar nossos artistas, impressionarse com a coragem dos negros [...] É imaginar homens e mulheres em trajes de época andando pelas ruas, apeando de seus cavalos, conversando nas esquinas. Como numa cidade cenográfica, imagens de nosso faroeste colonial, tropeiros atravessando a serra, aventureiros cobiçando ouro, inconfidentes tramando levantes. (Tribuna de Minas, 1998, p. 27) 
O turista mais sofisticado que vai a Tiradentes não se prende diretamente aos apelos desses folhetins de uma mídia padrão. Mas, sem dúvida, na sua interação com a cidade, a partir de certos clichês e de um imaginário preconcebido, produz uma auto-imagem de si em cima de uma vivência ora mais próxima do religioso, ora mais próxima do histórico e cultural. O fato é que essa ambientação histórica e colonial contribui para uma redefinição da identidade do indivíduo que visita a cidade em torno da idéia de autenticidade, "tradição" e de "nação", que acrescenta ao seu lado moderno e cosmopolita uma experiência complementar de si, através de um olhar para a experiência deste "outro" nativo.

De fato, como demonstrou Steil (1998) em estudo sobre "turismo religioso" nas cidades de Gramado e Canela, Sul do país, a condição de ser turista é saber sustentar um "olhar exótico", que possibilita um distanciamento simbólico em relação aos que não compõem seu grupo original. Viajar não significa apenas conhecer outros modos de vida, mas também se reconhecer na forma de ser de seu grupo social ou área cultural de pertença. Trata-se de uma pedagogia "onde a transação cultural com o outro permite estabelecer uma melhor definição de si" (Steil, 1998, p. 3) e conclui citando a afirmação de Rachid Amirou de que "o olhar turístico torna-se uma máquina de produzir a diferença".

\section{Conclusão}

Para concluir, gostaríamos de sintetizar como cada matriz, religião, patrimônio histórico e turismo, ativa suas estruturas de significado de uma forma exclusiva, na produção de sentido para construir seu "mundo próprio", como também observar possibilidades de interação e circulação na produção de significados entre as matrizes, umas em relação às outras.

A religião católica em Tiradentes elabora sua estrutura de significados mobilizando principalmente mecanismos de identificação e projeção das pessoas em relação aos santos, antepassados e deidades, mediada pela idéia central de sacrifício, dando assim ao devoto a possibilidade de pensar o mundo terreno em contigüidade com o mundo transcendente.

A ação e a idéia de patrimônio cultural constitui uma lógica analítica, onde igrejas, imagens e rituais adquirem um sentido para além do religioso, quando são aglutinados a partir de sua especificidade no conceito de "identi- 
dade nacional". A partir dessa lógica historiciza-se a vivência religiosa tradicional e enfatiza-se seu lado de criação artístico-cultural em detrimento de seu sentido transcendente.

Através do turismo, o indivíduo pode exercitar um olhar que, ao se identificar com a cultura e religião do outro, no mesmo movimento se diferencia dele, reforçando seu próprio locus identitário. Pelo seu caráter de consumo, o turismo proporciona uma experiência única, onde o sujeito pode compor vários sentidos, religiosos, históricos, culturais, ressignificando-os em busca de uma satisfação pessoal.

Estudando o caso da representação da Paixão de Cristo em Nova Jerusalém, Ortiz centra seu foco na prevalência do aspecto turístico e do lazer sobre o religioso, como dimensões excludentes:

[...] a história sagrada se reduz ao puro espetáculo teatral... a obra não é mais sentida em seu "valor de culto", é apreciada unicamente em seu aspecto de exposição. Falar nessa condição de elemento numinoso seria pura contradição, o público não se situa mais na posição de recolhimento, mas sim no pólo oposto, o da diversão [...] não se trata, como antes, de uma evasão mística, na qual o indivíduo se perde, se aniquila diante da potência do "tremendum mysterium" [...] As manifestações religiosas são assim coisificadas, elas perdem o sentido sagrado, tornando-se produtos mecanicamente distribuídos pela indústria cultural. (Ortiz, 1980b, p. 58).

Essa visão, contudo, reduz toda a possibilidade de comunicação e porosidades entre as duas dimensões, quando o turista pode passar de uma apreciação puramente cultural ou de lazer para ir ao encontro de uma experiência do intangível, mesmo que essa vivência não seja como a do nativo. Ao contrário de Ortiz, através de nossa pesquisa constatamos que muitos turistas que vão a Tiradentes na Semana Santa possuem uma empatia para com o sacrifício do devoto. Depoimentos desses turistas falam de viagens que fizeram antes a Aparecida do Norte para acompanhar a romaria, e da impressão causada pelo sacrifício dos romeiros que carregavam pedras na cabeça ou se arrastavam em procissão com os joelhos esfolados. Também mencionam a ida ao Círio de Nazaré, quando se deslocaram da sacada confortável destinada aos observadores para sentir um pouco daquela massa pujante de pessoas que se engalfinhavam para tentar 
colocar a mão no cordão. Em Tiradentes, muitos acompanham as procissões envolvidos por lembranças de infância, ou tocados pela nostalgia de uma "tradição" que nunca viveram.

Aqui poderíamos fazer, então, de uma forma mais benevolente - conquanto não reduzida apenas a consumo e lazer e tratamento do outro como exótico - uma associação das motivações do turista com aquelas do próprio antropólogo, que na sua busca, um tanto árdua e peregrínica, por conhecer uma alteridade tão distante de si mesmo, a pretexto de querer refletir sobre este outro longínquo, termina por reunir elementos e sabedorias para pensar, a partir deles, sobre nós mesmos e sobre nossa cultura.

\section{Referências}

BATAILLE, Georges. A noção de despesa: a parte maldita. Rio de Janeiro: Imago, 1975.

BOLETIM INFORMATIVO DO PATRIMÔNIO HISTÓRICO- IPHAN, 13 $3^{\text {a }}$ Superintendência Regional, São João Del Rei, n.15, abr.jun 2000.

BRANDÃO, Carlos Rodrigues. Ouro Preto: arte, antigüidade e artesanato. A CULTURA da rua. Campinas: Papirus, 1989.

DUVIGNAUD, Jean. Festas e civilizações. Rio de Janeiro: Tempo Brasileiro, 1983.

ELIADE, Mircea. Mito e realidade. São Paulo: Perspectiva, 1972.

GIOVANNINI, Oswaldo. Cidade presépio em tempo de Paixão: turismo e religião: tensão, negociação e inversão na cidade histórica de Tiradentes. In: BANDUCCI Jr., Álvaro; BARRETO, Margarida (Org.). Turismo e identidade local: uma visão antropológica. Campinas, Papirus, 2001.

GONÇALVES, José Reginaldo. A retórica da perda: os discursos do patrimônio histórico no Brasil. Rio de Janeiro: UFRJ: IPHAN, 1996.

HERVIEU-LÉGER, Daniele. La religion des européens: modernité, religion secularization. In: DAVIE, G.; HERVIEU-LÉGER, D. (Ed.). Les identités religieuses en Europe. Paris: La Découverte, 1996. p. 9-23.

LÉVI-STRAUSS, Claude. Antropologia estrutural I. Rio de Janeiro: Tempo Brasileiro, 1991. 
MAGALHÃES, Aloísio. Bens culturais: instrumentos para um desenvolvimento. Revista do IPHAN, Rio de Janeiro, n. 20, p. 35-48, 1984.

MAUSS, Marcel. Ensaio sobre a Dádiva. In: Sociologia e Antropologia. São Paulo: EDUSP, 1974. v. 2.

ORTIZ, Renato. A consciência fragmentada: ensaios de cultura popular e religião. Rio de Janeiro: Paz e Terra, 1980a.

ORTIZ, Renato. Religiões populares e indústria cultural. Religião e Sociedade, Rio de Janeiro, ano 3, n. 5, p. 51-93, 1980 b.

OTTO, Rudolf. O sagrado. São Paulo: Ed. Imprensa Metodista, 1955.

PACE, Enzo. Religião e globalização. In: ORO, A. P.; STEIL, C. A . Religião e globalização. Petrópolis: Vozes, 1997.

SANCHIS, Pierre. A caminhada ritual. Religião e Sociedade, Rio de Janeiro, ano 6, n. 9, p. 16-26, jun. 1983.

STEIL, Carlos Alberto. Peregrinação e turismo: o Natal em Gramado e Canela. In: REUNIÃO ANUAL DA ANPOCS, 22., 1998, Caxambu. 1998. p. 1-17.

TRIBUNA DE MINAS. Suplemento Literário Cidades de Minas, Tiradentes e São João Del Rei, Juiz de Fora, 1998.

TRIBUNA DE MINAS. Juiz de Fora, 5 abr. 2000.

ZALUAR, Alba. Promessas e milagres dos santos. In: OS HOMENS de Deus. Rio de Janeiro: Museu Nacional, 1974.

Recebido em 04/08/2003 Aprovado em 20/08/2003 